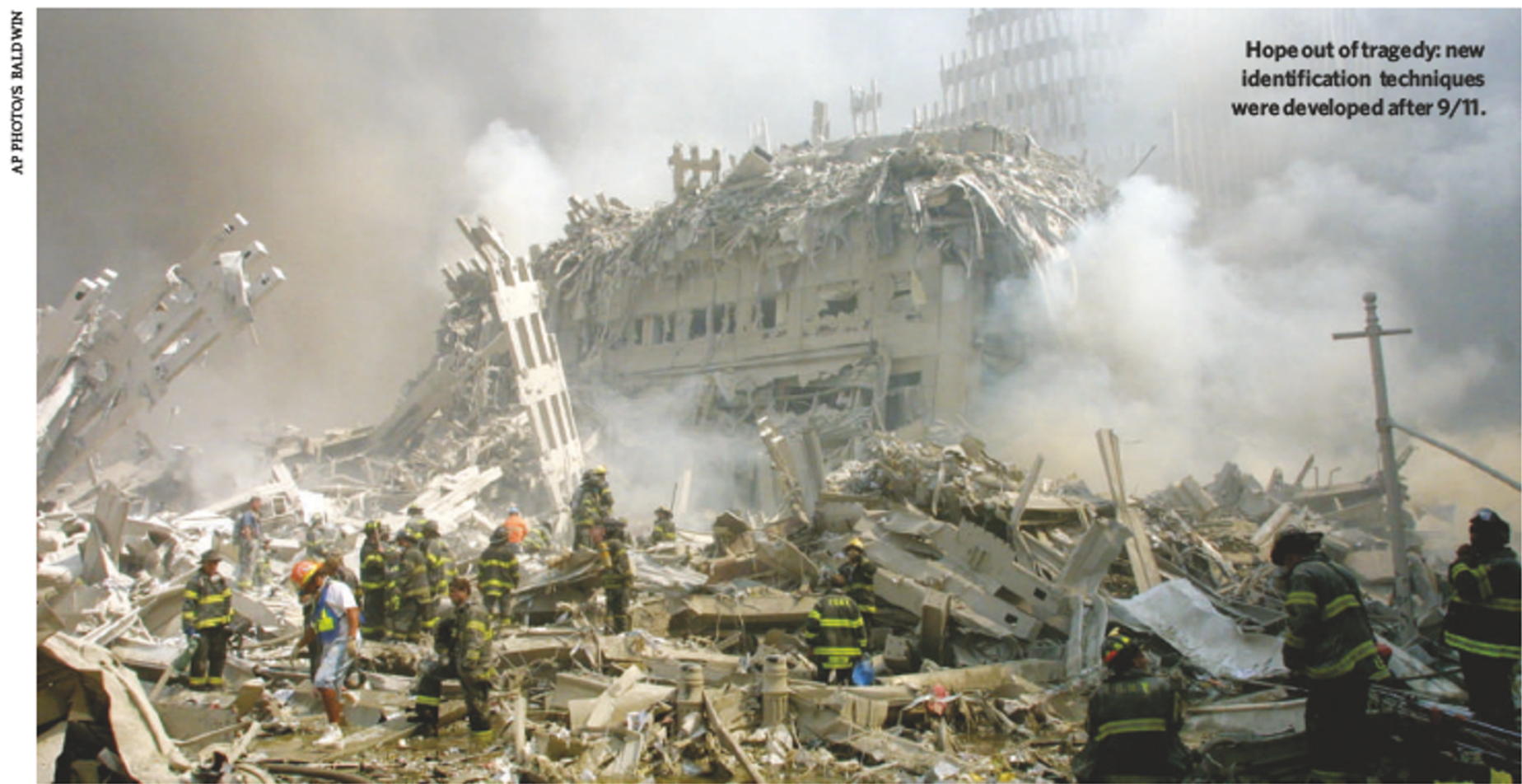

\title{
Disasters drive DNA forensics to reunite families
}

\section{HELSINKI}

Forensic tools developed because of the terroristattacks of 11 September 2001 and the Indian Ocean tsunami of 26 December 2004 could soon

find a happieruse - helping reunite Jewish familiesseparated by the Holocaust.

The DNA Shoahproject, announced on 1 June at the Human Genome Organisation's meeting in Helsinki, Finland, is the brainchild of Syd Mandelbaum, whose parents survived the Holocaust, or Shoah as it is known in Hebrew.

Working with Michael Hammer, a geneticist at the University of Arizona in Tucson, Mandelbaum has launched a database of the DNA of survivors. The hope is to match sequences with Holocaust-era remains that have surfaced in landdevelopmentprojects in Poland, Germany and elsewhere in Europe. Another aim is to reunite some of the families of around 10,000 Holocaust orphans sent abroad from mainland Europe to Israel, the United States, Britain and elsewhere between 1945 and 1950.
It is a difficult task. After more than 60 years in the ground, DNA will be degraded. And there are few reference sequences to compare it with: so many people were murdered that inmany families all immediate relatives were killed. Matching distant relatives is statis tically much harder.

Findings from more recent disasters could help. At the World Trade Center in New York, where more than 2,700 died in the $9 / 11$ attacks, fire degraded DNA to the point that standard DNA fingerprinting could not give a reliable match (L. G. Biesecker et al Sdience 310, 1122-1123; 2005). Inves tigators turned to mitochondrial DNA, which is more plentiful and robust than the commonly used nuclear DNA. They also adopted a method calledSNP typing, which works with smaller pieces of DNA. Yet, individually, none of these methods was precise enough to identify most remains.

"It pushed the science to try more innovative techniques," says Richard Leary, managing director of the company Forensic Pathways, based in Staffordshire, UK.

Gene Codes Forensics, a bioinformatics firm based in Ann Arbor, Michigan, developed software to integrate different kinds of DNA data and other forensic information. On the first day the system was used, 13December 2001, itmade more than 80 new matches, which helped identify $\mathbf{5 5}$ people who hadbeen killedat the World Trade Center. So far, 1,598 victims have been identified by all means.

Identifying those killed by the Asian tsunami posed different problems. The wave swept away houses containing per sonal items, such as hairbrushes, thatcould provide DNA samples, and also killed many family members at once, says Kirsty Wright, a forensics expertat the Queensland Health and Scientific Services in Brisbane, Australia, who helped identify victims. As well as multiple DNA profiling methods, the teams needed software that could match victims with distant relatives.

Wright is now working on ways to
SENIOR SPERM ARE

LESS FIT

Men, preparetohear the

ticking of your biological clock

www.nature.com/news identification techniques were developed after $9 / 11$. match the DNAs of deadpeople with each other, so that multiple victims in one family can be identified simultaneously.

The software from Gene Codes, which is among those that can match distant relatives, will handle the Shoah data. But time is running out. There are some 300,000 known Holocaust survivors, with an average age of 68. Mandelbaum and Hammer hope soon, with the help of the US Holocaust Memorial Museum in Washington DC, to start collecting DNA from cheek swabs.

For Howard Cash, president of Gene Codes, the idea that his firm's software could be used to bring good news is welcome. "Our team has dealt withsuchterrible circumstances," he says. "They would be overjoyed to reunite someone with a family member they thought was lost."

Leary says ithighlights the potential of DNA forensics. "The issue for geneticists is to use this science in a very wide and imaginative way," hesays.

Claire Ainsworth 